\title{
POSISI NON-MUSLIM DALAM HUKUM ISLAM: SUATU TINJAUAN ATAS PANDANGAN FAKIH KLASIK
}

Oleb: Ayang Utriza Nway*

Abstract

One of non-muslim anxieties in the Islamic world is about their status. They are treated as second class of citizen of country. And the most difficult problem is why does Islamic law whicb references to Islam, force to apply for non-muslim, like Christian, Jews, Zoroastrian. This article attempts to describe about their status in Islamic jurispridence (fiqb) of Sunni's schools (Hanafi, Maliki, Syafi'i and Hanbali). The article describes their perspective based on the literature survev which references to main books of those schools in the thought of those faaibs.

إن أحل المتحاوف اليت تنتاب غير المسلمين المقيمين في الدول الإسالمية تنبع من قراءتمم لموتقهم حينما يتم تطبيت الشريعة الإسالمية؛ حيتث يظنون أنـــه سينظر إليهم باعتبارهم مواطنين من اللدرجة التانية. ثمة إشكالية أخرى تــير كثيراً من اللحلد في هذا الصدد، وهي المتعلقة بالتساؤل "لماذا يتم تطبيت نظام

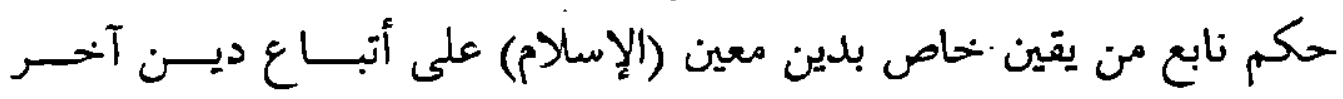
كالنصارى، اليهود، البحوس والزارادشتين؟؟". تبحت هذه المقالــة في تلــلك التساؤلات، عير تقصيها لمكانة غير المسلمين في الفقه الإســلامي .مذاهبــه الأربعة، وذلك عبر بكث مبكتي ير جع إلى أمهات كتب كل مذهب من تلك المذاهنب حول هذه المسألة.

Keywords : Abl Kitâb, Dâr al-Islâm, Dâr al-Harb, Ahl Dzimmah, Jiz̧ah.

* Peneliti Pusat Studi Islam dan Kenegaraan (PSIK) Universitas Paramadina Jakarta dan Dosen Fakultas Syariah dan Hukum UIN Syarif Hidayatullah Jakatta. Kandidat doktor di Ecole des Hautes Etudes et Sciences Societes (EHESS) Paris, Prancis. Email: ayang_uttiza@yahoo.com 


\section{A. Pendabuluan}

Hukum Islam membedakan antara Ahlul Kitab dan Musyrik, walaupun status keduanya sama-sama kafir'. Para ahli hukum Islam (fuqabâ'/faqîh) membedakan keduanya atas dasar ayat "Dan belumlah orang-orang kafir dari ablul kitab dan musyrik itu percaya sebelum datang kepada mereka sebuab keterangan yang nyata') Menurut fukaha, Ahlul Kitab adalah mereka yang menerima kitab, seperti Yahudi dan Nasrani, sementara Musyrik adalah mereka yang tidak punya agama, yaitu para penyembah berhala, arwah, pepohonan dan lain-lain ${ }^{3}$.

Fukaha berbeda pendapat tentang Sabi'ah (penyembah bulan dan bintang) dan Majusi (penyembah api). Menurut Mujahid (w. 104 H./722 M.), Sabi'ah adalah segolongan Ahlul Kitab juga yang membaca Zabur. Demikian pula menurut Abu Hanifah (Kufah-Baghdad, 80-150 H./699-767 M.), tetapi ia menambahkan bahwa Sabi'ah golongan Ahlul Kitab yang menyimpang seperti Yahudi dan Nasrani. Adapun Majusi, menurut Abu Tsaur (w. 240 H./854 M.), juga termasuk Ahlul Kitab, sebab mereka mengakui membayar jizyah seperti Yahudi dan Nasrani ${ }^{4}$. Demikian juga menurut Daud Zhahiri (w. 270 H./883M.), karena mereka halal dinikahi seperti Ahlul Kitab ${ }^{5}$. Sementara menurut Syafi'i (Gaza-Kairo,150-204 H./767-820 M.) dan Hanbali (Baghdad, 164-241 H./780-855 M.) bahwa Majusi dan Sabi'ah bukanlah bagian Ahlul Kitab ${ }^{6}$. Namun demikian di beberapa pembahasan, mereka memasukkan Majusi dan Sabi'ah dalam golongan Ahlul Kitab.

Makna non-muslim dalam artikel ini merujuk kepada Ahlul Kitab sebagaimana yang disepakati oleh fukaha. Adapun bahan yang dijadikan sumber kajian dalam tulisan ini ialah empat madzhab ortodoks Sunni yang, sebagaimana kita akan lihat nanti, memberikan hukum yang saling berlainan terhadap non-muslim.

\section{B. Konsep Dasar : Dâr al-Islâm dan Dâr al-Harb}

Nabi Muhammad saw. berhasil membangun komunitas muslim cukup kuat di Madinah. Beliau menaklukkan suku-suku dan daerah di sekitamya agar tunduk di bawah kekuasan Islam. Tahap selanjutnya, perkembangan Islam sangat pesat pada abad-abad pertama Hijriyyah melalui penaklukkan-penaklukkan yang dilakukan oleh

1 Dalam kitab-kitab fikih, para Fukaha sering menyebut Ahlul Kitab dan kafir. Kafir di sini memiliki pengertian yang umum, yaitu bisa musyrik dan kafir arab.

${ }^{1}$ QS. Al-Bayyinah/ $98: 1$.

${ }^{2}$ Sayyid Sâbiq (1409/1988), Fiqh Sunnah, Beirut Darul Fikr. Jilid. II, p. 91.

${ }^{3}$ Sâbiq, op.cit., Jilid. II, p. 92.

4 ‘Abd Rahmân al-Jazîn (1987/1406), Kitâb al-Figh Alâ Madzbâbi al-Arba'ah, V Jilid, Beirut: Dâr alFikr, Jilid. VI, p. 75.

${ }^{5}$ Sâbiq, op.cit., Jilid. II, p. 93.

'Bat Ye'Or (1980), Le Dbimmi: Profil de l'Opprimé en Orient et en Afrique du Nord Depuis la Conquête Arabe, Paris: Anthropos, pp. 23-25. 
bala tentara Islam. Daerah kekuasaan dan taklukan Islam yang begitu luas telah menimbulkan masalah sendiri: di satu sisi tentang status dan hubungan non-muslim yang hidup di daerah kekuasaan umat Islam. Dan di sisi lain, keberadaan umat Islam, yang masih minoritas kala itu di tengah masyarakat Kristen dan Majusi, membutuhkan perangkat hukum yang jelas. Oleh karena itu, para penguasa dan fukaha, yang terinspirasi oleh Alquran dan Sunnah, mengatur hubungan antara muslim dengan penduduk asli yang tunduk pada penguasa Islam?

Fukaha membagi dunia ini menjadi 2 wilayah politik-agama: Dâr al-Islâm, daerah Islam dan Dâr al-Harb, daerah perang. Dâr al-Islâm adalah wilayah yang dikuasai umat Islam, sementara Dâr al-Harb adalah wilayah di luar kekuasaan Islam $^{8}$. Dâr al-Islâm juga berarti wilayah di mana hukum islam diterapkan kepada penduduknya. Sementara di dalam Dâr al-Harb hukum Islam tidak berlaku. Dâr alIslâm selalu dalam keadaan perang dengan Dâr al-Harb. Keadaan permusuhan itu tak akan bethenti, hingga Dâr al-Harb tunduk ke dalam Dâr al-Islâm? . Dalam keadaan perang seperti itu, ada tiga tawaran yang diajukan pihak Islam kepada non-muslim: masuk Islam, dibunuh, atau tunduk kepada penguasa Islam dengan membayar jizyah ${ }^{10}$.

Bagi non-muslim yang tidak mau masuk Islam dan tak tunduk kepada otoritas penguasa Islam dinamakan barbi (musuh). Wilayah tempat tinggal mereka dinamakan Dâr al-Harb. Tidak ada jaminan keamanan bagi barbi, tidak juga hidup dan hartanya, singkatnya tak ada perlindungan hukum baginya ${ }^{11}$. Mereka inilah yang disebut di atas dalam keadaan permusuhan terus-menerus dengan Dâr al-Islâm.

Sementata bagi non-muslim yang tunduk pada penguasa Islam, mereka tinggal di Dâr al-Islâm dengan syarat membayar jizyah. Para fakih mendasarkan pendapatnya pada firman Allah «Perangilah mereka yang tidak beriman kepada Allab ... bingga mereka

${ }^{7}$ al-Jazîrî, op.cit., Jilid. VI,p. 199.

${ }^{8}$ Hervé Bleuchot (2002), Drit Musulman, Aix-en-Provence: Presses Universitaires d'Aix Marseille, Jilid. II, p. 589.

'Betdasarkan hadis Nabi « Jika kamu bertemu dengan musuh orang kafir ajak mereka masuk islam, jika mereka menjawab, cukuplah itu, jika tidak mau masuk islam, suruh meteka membayar jizyah, jika mereka mentaati, cukuplah itu, jika tidak juga, bertawakkallah pada Allah dan bunuh mereka. Tapi, Jika mereka mau masuk islam atau bayar jizyah, cukuplah bagimu. "

${ }^{10}$ Joseph Schacht (1999), Introduction au Droit Musulman, penterjemah Paul Kempf dan Abdel Magid Turki, Paris: Maisonneuve \& Larose, p. 112.

${ }^{11}$ QS. al-Taubat/ $9: 29$.

${ }^{12}$ Besarnya j̈zyah adalah 1 dinar, seperti riwayat Muadz bahwa Rasulullah menyuruhnya, ketika iaakan ke Yaman, untuk meminta setiap orang dewasa di Yaman 1 dinar atau sebanding dengan satu baju yaman. Lihat Sâbiq, opcit., jilid. II, p. 64. Namun ada pendapat lain mengatakan bahwa jizyah bagi yang miskin sebesar 1 dinar (12 dirham), bagi kelas menengah 2 dinar (24 dirham) bagi yang kaya 4 dinar (48 ditham) lihat C.H. Becker, "Djizya" (1913), dalam Engrclopédie de l'Tslam, diedit oleh M. Th. Houtsma, R. Basset, TW. Arnold dan R. Hartmann, Leiden dan Paris: EJ. Brill dan Picard, p. 1082. 
membayar jizyah...23». Jizyah, berasal dari kata jazâ, artinya sejumlah uang yang dibayatkan kepada penguasa wilayah umat Islam (Dâr al-Islâm) ${ }^{13}$. Siapa saja yang membayar jizyah maka disebut abl dzimmab ${ }^{14}$.

. al-Jurjânî mengatakan bahwa Dĩimmah secara bahasa adalah perjanjian ${ }^{15}$. Ibn Manzhur menjelaskan bahwa makna D zimmah adalah perjanjian, keamanan, jaminan, kehormatan dan hak. Subyek dzimmab dinamakan abl dzimmah, karena mereka masuk dalam perjanjian keamanan dengan kaum muslimin. Abu Ubayd berkata dzimmah adalah keamanan sebab diberikan keamanan terhadap abl dzimmab yang diambil darinya jizyah ${ }^{16}$. Jadi, Abl dzimmab adalah mereka yang membayar jizyah dengan mengadakan ikatan perjanjian patuh dan tunduk kepada penguasa umat Islam. Yang membayat jizyah adalah lelaki dewasa. Adapun perempuan, anak-anak dan orang tua tidak dikenakan jizyah.

Abl dzimmah tinggal bersama-sama dengan umat Islam lainnya di Dâr al-Islâm, dan berlaku hukum Islam pada diri mereka, sebagaimana berlaku bagi diri setiap umat Islam ${ }^{17}$. penerapan itu benar-benar bersifat teritorial, artinya hukum Islam itu tidak diterapkan kecuali bagi mereka yang tinggal di negara Islam (Dâr al-Islâm) ${ }^{18}$.

Namun, mengenai siapa yang disebut abl dzimmah, fukaha berbeda pendapat. Menurut Syafi'i hanya Ahlul Kitab dan Majusi saja yang boleh menjadi abl drimmah, adapun Musyrik, yaitu penyembah berhala tidak diterima sama sekali ${ }^{19}$. Menurut Hanbali, selain Ahlul Kitab, Majusi dan Samira juga dapat menjadi abl dzimmab ${ }^{20}$. Sementara menurut Malik (Madinah, 94-179 H./716-795 M.) dan Hanafi musyrik pun bisa menjadi abl dqimmab ${ }^{21}$. Selain barbi dan dzimmi, ada bentuk ketiga yaitu mustakmin. Mustakmin adalah hatbi yang dijamin oleh seorang muslim mukallaf, baik lelaki atau perempuan, agar dapat tinggal di Dâr al-Islâm dan dia tidak membayar jizyah $^{22}$.

${ }^{13}$ Sâbiq, op.cit., p. 65.

14 'Ali ibn Muhammad al-Jurjânî (1978), Kitâb al-Ta'rifât. Beirut: Maktabat Lubnân, p. 112.

${ }^{15}$ Ibn Mandzhûr (tanpa tahun), Lisân al-'Arab, Beirut: Dât al-Ma'ârif, Jilid III, pp. 1517.

${ }^{16}$ Hasan al-Mimmî (1998), Ahl dz̧immah Fî al-Hadlârat al-Islâmíyyat, Beirut: Dâr al-Gharb al-Islâmî, p. 27.

${ }^{17}$ Louis Millot dan François-Paul Blanc (1987), Introduction à l'Etude du Droit Musulman, Paris: Sirey, p. 226.

${ }^{18}$ Muhamad Ibn Idrîs al-Shâfi'i (tanpa tahun), al-Umm, (ed.) Muhammad Zuhri al-Najjât, Beirut: Dâr al-Ma'rifat, Jilid. N, p. 174.

${ }^{19}$ Shamsuddîn Ibn Qudâmah-(tanpa tahun), al-Sharb al-Kabîr, Beirut:Dâr al-Fikēr, Jilid. V, p. 604.

${ }^{20}$ Sâbiq, op.cit., p. 67, lihat juga Babet Johansen (1999), "The Muslim Fikh as a Sacred Law. Religion, Law and Ethics in a Normative System," dalam Contingency in Sacred Law: Legal and Ethical Norms in the Muslim Fikh, 3-72 p, Leiden: Brill, p. 68.

${ }^{21}$ Schacht, op.cit., p. 112.

${ }^{2}$ Lihat Shamsuddîn al-Sarakhsî (1994/1414), al-Mabsût, XXX Jilid, Beirut: Dât al-Kutub al- 


\section{Hukum.Islam yang Diterapkan kepada non-Muslim}

Seperti telah dinyatakan di atas bahwa abl dzimmab (selanjutnya disebut nonmuslim) yang hidup di Dâr al-Islâm berlaku hukum Islam bagi mereka. Di bawah ini, akan dipaparkan beberapa contoh bagaimana hukum Islam diterapkan bagi nonmuslim.

\section{Pernikahan dengan non-Muslim}

Para fakih 4 madzhab: Hanafi, Maliki, Syafi'i dan Hanbali sepakat bahwa laki-laki muslim dapat menikahi perempuan non-muslim, sementara laki-laki nonmuslim tidak bisa menikahi perempuan muslim selamanya ${ }^{23}$. Fukaha mendasarkan pendapatnya pada QS. al-Mâ'idah 5:5 “...Dan makanan Ablul Kitab balal bagi kalian, dan makanan kalian balal bagi mereka, begitu juga menikabi wanita muslimab yang mubshan dan wanita mubshan dari Ablul Kitab..." Namun, Maliki memakruhkan menikahi wanita non-muslim yang tinggal di Dâr al-Islâm. Alasan Malik, sebab perempuan non-muslim itu makan babi dan minum khamat yang akan mempengaruhi anak yang dikandungnya ${ }^{24}$. Adapun Hanafi dan Syafi'i memakruhkan menikahi perempuan nonmuslim yang tinggal di Dâr al-Harb' ${ }^{25}$.

Hukum keluarga yang digunakan bagi wanita non-muslim yang menikah dengan pria muslim ialah hukum Islam. Jadi, masalah talak, ruju', khulu', nafkah dan kebolehan menikahi 4 perempuan, waktu dan giliran antata isteri, semuanya berdasarkan hukum Islam sebagaimana yang berlaku bagi wanita Islam ${ }^{26}$.

Secara sosiologis, pelarangan menikahi wanita muslim oleh pria non-muslim dapat dipahami, karena jumlah wanita muslimah yang sangat sedikit waktu itu. Ada kekhawatiran bahwa wanita muslimah yang dinikahi akan mengikuti agama suami yang non-muslim, karena kedudukan suami dalam rumah tangga sangat dominan di masyarakat Timur-Tengah yang sangat 'lelaki.' Posisi suami yang memegang kendali tersebut ditakutkan akan membuat istrinya yang muslimah keluat dari agama Islam. Karena itulah, pernikahan wanita muslimah dengan pria non-muslim dilarang. Namun, jika keadaan telah betubah seperti saat ini: jumlah wanita muslimah sangat besat dan dominasi istri dalam rumah tangga semakin kuat, apakah hukum Islam juga akan berubah? Suara-suara dan cakrawala baru sudah cukup banyak dilontarkan

Ilmiyyah, Jilid V, p. 38, 50. Shâfii, op.cit., Jilid. IV, p. 182, 269, Jilid. V, p. 6, 7, 269. Sâbiq, op.cit., Jilid. II, pp. $-90-94$.

${ }^{23}$ Sahnûn Ibn Sa'ad al-Tanûkhî (tanpa tahun), al-Mudannanat al-KubrấLi al-Imâm Mâlik, (ed.) 'Ali Ibn Abd Rahmân al-Hâshimî, XI Jilid, Kairo:Dât al-Nasht, Jilid IV, pp. 105-6.

${ }^{24}$ al-Sarakhsî, op.cit., Jilid V, p. 50; Shafi'i, op. cit., Jilid IV, p. 266.

${ }^{25}$ al-Sarakhsî, op.cit., p. 200, Shâffi', op.cit., Jilid.V, pp. 204, 243, Muwaffaq al-Dîn Ibn Qudâmah, (1983/1403), al-Mugbnî, XIII Jilid, Beirut: Dâr al-Kutub al-'Araby, Jilid IX, pp. 76, 253-55.

${ }^{26}$ al-Tanûkhî, op.cit., Jilid IX, pp. 8, 9, 12, 13.

${ }^{27}$ al-Tanûkhî, op.cit., Jilid IX, pp. 13-14.

${ }^{28}$ al-Tanûkhî, op.cit., Jilid IX, p. 87. 
para pemikir muslim, tapi dapatkah mereka menentang arus utama fikih klasik yang masih dominan di tengah masyarakat Islam hingga hari ini? Waktu yang akan menjawabnya.

2. Kesaksian Non-muslim

Menurut Malik, Kesaksian non-muslim terhadap orang Islam tidak diterima ${ }^{27}$. Bahkan, menurut Malik, persaksian antara non-muslim ditolak, hanya muslim yang diterima kesaksiannya dan bethak memberikan kesaksian atas kasus antar mereka ${ }^{28}$. Malik juga tidak menerima sumpah non-muslim. mereka boleh bersumpah, tapi harus menyebut nama Allah ${ }^{29}$. Menurut Syafi'i kesaksian non-muslim ditolak selamanya, baik tethadap muslim atau sesama non-muslim, sebab menurutnya, persyaratan untuk bersaksi adalah Islam, dengan sendirinya persaksian non-muslim tertolak, kecuali setelah masuk Islam ${ }^{30}$.

Menurut Hanafi persaksian non-muslim ditolak, sebab syarat memberikan kesaksian adalah Islam, kecuali dalam keadaan darurat seperti wasiat muslim yang akan meninggal dan sedang dalam perjalanan, atau ketika tak ada lagi orang muslim, maka persaksian non-muslim dapat diterima. Walaupun, menurut Hanafi, kesaksian non-muslim terhadap muslim tidak diterima ${ }^{31}$. Namun, Hanafi memberikan hak persaksian bagi non-muslim terhadap non-muslim lainnya, jika ada suatu kasus atau masalah antar mereka ${ }^{32}$. Bahkan, persaksian non-muslim diterima terhadap muslim penjamin (mustakmin). Alasan Hanafi, non-muslim yang dijamin itu tinggal di wilayah umat Islam, karenanya memiliki kedudukan yang sama dalam memberikan kesaksian seperti muslim ${ }^{33}$.

Dari semua madzhab yang disebutkan, hanya madzhab Hanafi yang memberikan hak bersaksi bagi non-muslim dalam kasus antar mereka, bahkan untuk memberikan persaksian terhadap muslim yang memberikan jaminan. Sementara madzhab lainnya sama sekali menghapus hak non-muslim untuk bersaksi, sekalipun bersaksi dalam kasus antar mereka.

3. Tindak Pidana oleh Non-Muslim

Semua sanksi hukum pidana Islam berlaku bagi non-muslim yaitu rajam bagi penzina, potong tangan bagi pencuri, cambuk bagi penuduh zina, kisas bagi pembunuh, bunuh bagi penyamun, kecuali minum khamr (minuman yang memabukkan), non-muslim tidak dikenai sanksi.

Menurut Hanbali semua hukum Islam yang betlaku bagi umat Islam betlaku bagi non-muslim seperti had zina, membunuh, mencuri dan qadzaf (menuduh

29 Shâfi'i, op.cit., Jilid. VII, p. 47.

${ }^{30}$ al-Sarakhsi, op.cit., Jilid IX, p. 74, Jilid. XII, p. 165, Jilid XIX, p.12.

31 al-Sarakhsi, op.cit., Jilid IX, p. 146, Jilid. XVIII, p. 170, Jjlid XIX, p. 12.

32 al-Sarakhsi, op.cit, Jilid XVI, p. 139.

${ }^{33}$ Ibn Qudâmah, op.cit., p. 619. 
betzina $)^{34}$. Menurut Syafi'i, hukum non-muslim dalam tindak pidana pembunuhan sama seperti yang berlaku bagi muslim. Pelaku pidana zina non-muslim dirajam. Sementara untuk tindak pidana minum khamar tidak dikenai sanksi, sebab khamar itu halal bagi mereka. Pembayatan diyat (uang penggantian) atas tindak pidana yang dilakukan oleh non-muslim seperti yang berlaku bagi muslim. Tapi sebaliknya, jika non-muslim yang berhak mendapat pembayaran diyat, penggantiannya lebih sedikit, seperti diyat janin non-muslim hanya sepersepuluh diyat budak, kecuali jika bapaknya muslim, maka diyatnya seperti diyat bayi mukmin ${ }^{35}$.

Menurut Maliki, dalam tindak pidana zina, jika lelakinya muslim dan perempuannya non-muslim, baik di Dâr al-Islâm maupun di Dâr al-Harb, maka lelakinya dirajam, sementara wanita non-muslim diserahkan urusannya menurut ketentuan agamanya ${ }^{36}$. Tindak pidana qadzaf yang dilakukan muslim terhadap nonmuslim atau sebaliknya, dikenai sanksi had cambuk ${ }^{37}$. Tindak pidana pencurian yang dilakukan non-muslim adalah potong tangan seperti yang betlaku bagi muslim. Adapun tindak pidana minum khamar tidak dikenai sanksi ${ }^{38}$. Untuk tindak pidana pembunuhan yang dilakukan oleh non-muslim terhadap muslim atau sebaliknya, hukumannya sama dengan yang betlaku bagi muslim ${ }^{39}$. Namun untuk diyat nonmuslim, baik lelaki maupun wanitanya, hanya setengah dari diyat muslim ${ }^{40}$.

Menurut Hanafi tidak ada sanksi tindak pidana zina yang dilakukan nonmuslim, sebab syarat dirajam adalah harus ibsân (terjaga), dan ibsân menurut Hanafi adalah harus beragama Islam, karena mereka bukan orang Islam, makanya mereka tidak dirajam ${ }^{41}$. Begitu juga bagi mustakmin yang berzina dengan perempuan muslim atau perempuan non-muslim tidak dirajam. Untuk tindak pidana gadzaf yang dilakukan non-muslim sanksinya sama dengan muslim yaitu dicambuk ${ }^{42}$.

Dari semua pendapat di atas, hanya pendapat Hanafi yang dengan jelas mengatakan bahwa non-muslim itu tidak dikenai sanksi zina betupa rajam jika mereka berzina. Sementara bagi ketiga fukaha yang lain dengan sangat jelas menyatakan bahwa hukum Islam betlaku bagi non-muslim yang melakukan tindak pidana.

\section{Transaksi Ekonomi}

Menurut hukum Islam, dalam transaksi ekonomi seperti jual beli, non-muslim

\footnotetext{
${ }^{34}$ Shâfi'i, op.cit., Jilid VI, pp. 46, 111, 139.

${ }^{35}$ al-Tanûkhî, op.cit., Jilid XI, p. 20.

${ }^{36}$ al-Tanûkhî, op.cit., Jilid XI, pp. 37-38.

${ }^{37}$ al-Tanûkhî, op.cit., Jilid XI, p. 119.

38 al-Tanûkhî, op.cit., p. 365.

${ }^{39}$ al-Tanûkhî, op.cit., p. 311.

t0 al-Sarakhsî, op.cit., Jilid IX, pp. 39-40.

${ }^{41}$ al-Sarakhsî, op.cit., Jilid IX, pp. 41, 55, 85.

42 Sâbiq, op.cit., Jilid III, p. 65.
} 
dilarang melakukan riba ${ }^{43}$. Menurut Hanafi, non-muslim tidak boleh melakukan riba dalam transaksi ekonomi. Jika mereka melakukannya, mereka dikenakan sanksi had ${ }^{44}$. Tapi, mereka boleh melakukan riba di Dâr al-Harb ${ }^{45}$. Jual-beli dengan non-muslim dengan barang yang haram, menurut Hanafi, boleh dan sah, begitu juga menyewakan rumah kepada non-muslim untuk berjualan khamar. Masih menurut Hanafi bahwa menggadaikan barang antara non-muslim dan muslim itu boleh dan $\mathbf{s a h}^{46}$.

Menurut Malik, jual-beli yang dilakukan non-muslim sah dan boleh termasuk jual-beli budak muslim. Namun, untuk budak non-muslim, Malik dengan tegas mengatakan bahwa budak non-muslim dilarang jual-beli karena mereka suka berbuat riba ${ }^{47}$. Yang dilarang dalam jual-beli ialah berbuat riba. Karena itu, jual-beli oleh non-muslim dengan riba dilarang walaupun di Dâr al-Harb ${ }^{48}$. Mengenai usaha bersama antara non-muslim dan muslim tidak boleh, kecuali seluruh transaksi melibatkan keberadaan muslim ${ }^{49}$.

Menurut Syafi'i, non-muslim bebas melakukan perdagangan (jual-beli) dan tidak dipungut $j i z y a h$ (pajak) lagi ${ }^{50}$. Yang dilarang menurut Syafi'i adalah non-muslim melakukan riba dalam transaksi ekonomi itu. Menurut Hanbali non-muslim boleh melakukan transaksi jual-beli dan bekerjasama dengan muslim tapi tidak boleh melakukan riba dan jual-beli barang haram ${ }^{51}$. Non-muslim boleh membayar muslim untuk bekerja padanya ${ }^{52}$. Tapi muslim tidak boleh menjual budak muslim kepada non-muslim ${ }^{53}$. Adapun, menyewakan atau menjual tanah ke non-muslim, makruh hukumnya, sebab menurut Hanbali petnasukkan pajaknya akan hilang jika tanah itu dijual atau disewakan ke non-muslim ${ }^{54}$.

Dari keempat mazhab Sunni ini nampak bahwa ketiga mazhab memberikan ruang yang sangat sempit bagi non-muslim untuk melakukan transaksi ekonomi, hanya Hanafi yang memberikan kelonggaran bagi non-muslim untuk melakukan transaksi ekonomi, seperti jual-beli.

5. Wasiat, Waris, Sedekah dan Hibah non-Muslim

Menurut Malik, wasiat muslim kepada non-muslim atau sebaliknya itu dilarang,

${ }^{43}$ al-Sarakhsî, op.cit., Jilid IX, p. 89.

"4 al-Sarakhsî, op.cit., Jilid XIV, p. 56.

${ }^{45}$ al-Sarakhsî, op.cit., Jilid XIV, p. 168, Jilid. XVI, p. 38, Jilid. XXI, p. 149.

${ }^{46}$ al-Tanûkhî., op.cit., Jilid IX, p. 167. Berdasarkan firman Allah QS. al-Nisâ’/4:161.

\$ al-Tanûkhî., op.cit., Jilid VII, pp. 257, 263-4.

${ }^{48}$ al-Tanûkhî., op.cit., Jilid IV, p. 38. Lihat juga Khậlid 'Abd Rahmân al-'Tk (1993/1413), Mavvsû́atu al-Figh al-Mâliki, Damaskus: Dâr al-Hikmat, Jilid IV, p. 29.

${ }^{49}$ Shafi'i, op.cit., Jilid IV, p. 281.

50 Ibn Qudâmah, op.cit., Jilid V, p. 109.

${ }^{51}$ Ibn Qudâmah, op.cit., Jilid IV, p. 307.

${ }^{52}$ Ibn Qudâmah, op.cit., Jilid X, p. 406.

${ }^{53}$ Ibn Qudâmah, op.cit., Jilid II, pp. 592-3.

${ }^{5+}$ al-Tanûkhî, op.cit., Jilid X, pp. 35-36, 143-144. 
sebab syarat wasiat adalah harus adil dan non-muslim itu tidak adil ${ }^{55}$. Masalah waris non-muslim kepada muslim atau sebaliknya tidak boleh, sebab petbedaan agama menghalangi pewarisan antara mereka ${ }^{56}$. Hibah dan sedekah non-muslim kepada muslim atau sebaliknya diperbolehkan ${ }^{57}$.

Menurut Hanbali, wasiat antata non-muslim dan muslim diperbolehkan. Namun, non-muslim tidak boleh mewasiatkan atas al-Quran dan budak Islam serta apa yang dilarang oleh shariah seperti membangun gereja, jual-beli khamar dan babi ${ }^{58}$. Sedekah kepada non-muslim boleh selain sedekah fitrah ${ }^{59}$. Untuk masalah pewatisan, non-muslim tidak bisa mewarisi muslim dan sebaliknya, namun antat non-muslim bisa saling mewarisi ${ }^{60}$.

Menurut Hanafi, non-muslim tidak bisa mewarisi muslim dan sebaliknya ${ }^{61}$. Tapi, non-muslim boleh mewariskan antar mereka ${ }^{62}$. Hibah antara non-muslim dengan muslim boleh, namun tidak boleh memberi barang yang diharamkan seperti khamar ${ }^{63}$. Non-muslim tidak boleh berwasiat kepada muslim, karena wasiat itu adalah bagian dari wilayah (kuasa) dan tak ada kekuasaan non-muslim atas muslim. Menurut Syafi'i non-muslim tidak bisa mewarisi muslim dan sebaliknya ${ }^{64}$. Hibah juga diperbolehkan oleh Syafi'i selama bukan atas barang yang dilarang syariah.

Dari keempat pendapat fukaha Sunni di atas hak non-muslim dalam hal wasiat, hibah dan sedekah saling berbeda: ada yang membolehkan dan melatang. Sementara dalam hal waris, keempat mazhab sepakat melarang pewarisan antara muslim dan non-muslim.

6. Ibadat

Untuk masalah ibadat, non-muslim diberikan kebebasan menjalankan.ajaran agamannya ${ }^{65}$. Salah satu contoh adalah perjanjian yang diadakan oleh Nabi dengan orang-orang Kristen Najran, yang menjamin kelangsungan hidup lembaga-lembaga Kristen. Contoh yang lain adalah garis kebijakan yang diberikan Nabi kepada Mu'adz Ibn Jabal yang hendak berangkat ke Yaman "Tidak seorang Yahudi pun boleh diganggu menjalankan syariat agamanya sendiri." Hal ini sebagai imbalan dari

55 al-Tanûkhî, op.cit., Jilid X, p. 59.

${ }^{56}$ al-Tanûkhî, op.cit., Jjilid X, pp. 267, 317.

${ }^{57}$ Ibn Qudâmah, al-Mughnî, op.cit., Jilid VI, p. 530.

${ }^{58}$ Ibn Qudâmah, al-Mughnî, op.cit., Jilid XI, p. 110.

${ }^{59}$ Ibn Qudâmah, al-Sharh al-Kabîr, op.cit., Jilid IV, p. 77.

${ }^{80}$ al-Sarakhsî, op.cit., Jilid VII, p. 77.

6t al-Sarakhsî, op.cit., Jilid XXX, p. 30.

${ }^{62}$ al-Sarakhsî, op.cit., Jilid XI, p. 106.

${ }^{63}$ Shâfi'i, op.cit., Jilid IV, pp. 73, 83.

${ }^{6}$ Sâbiq, op. cit., Jilid III, p. 65.

${ }^{65}$ Ignaz Goldziher (1991), Pengantar Teologi dan Hukum Islam (Introduction to Islamic Theology and Law), penerjemah Hetsti Setiawan, Jakarta: INIS, pp. 31-2. 
pembayaran jizyah, mereka diizinkan menjalankan syariat agama masing-masing tanpa gangguan ${ }^{66}$. Namun, teks-teks hukum Islam menunjukkan pembatasan keberagamaan non-muslim, seperti yang dipaparkan di bawah ini.

Menurut Hanbali non-muslim dilarang membangun gereja, mengeraskan suara mereka ketika membaca kitab suci mereka, menampakkan khamar dan babi. Mereka dilarang menampakkan salib dan merayakan hari raya keagamaan mereka. Mereka juga dilarang membunyikan lonceng gereja, bahkan mereka dilarang mendirikan bangunan lebih tinggi dari umat Islam. Dalam penampilan kesehatian, non-muslim harus membedakan dirinya dari umat Islam mulai dari model rambutnya, bajunya, kendaraannya, serta panggilannya ${ }^{67}$.

Menurut Syafi'i pembangunan gereja di dekat pemukiman muslim dilarang. Bangunan non-muslim pun tidak boleh lebih tinggi dari bangunan muslim. Nonmuslim juga tidak boleh mengeraskan suaranya ketika mereka beribadah dan membunyikan lonceng. Dan jika mereka melakukannya, maka mereka dihukum ${ }^{68}$. Menurut Abu hanifah, tidak boleh membangun gereja baru, tapi boleh membenarkan bangunan ibadah yang rusak ${ }^{69}$. Mengenai pengurusan gereja, menurut Syafi'i dan Hanbali, non-muslim tidak boleh diberi hak milik dan pengurusan tempat ibadah, menurut Malik dan Hanafi mereka diberi hak milik dan pengurusan atas tempat ibadah mereka ${ }^{70}$. Non-muslim juga dilarang membawa senjata, tidak boleh naik kuda dan harus bersikap sopan kepada muslim ${ }^{71}$.

Hak non-muslim dalam kebebasan beribadat menjadi persoalan yang sangat pelik dan selalu menyebabkan perjanjian baru (mu'abadab) antara non-muslim dengan penguasa Dâr al-_slâm ${ }^{72}$. Sebagaimana halnya hak mendirikan gereja atau memperbaiki yang gereja yang telah rusak selalu menjadi masalah dalam hukum Islam ${ }^{73}$. Jadi, dalam urusan ibadah sekalipun, para fukaha memberikan ruang yang amat sangat sempit dan terbatas bagi non-muslim. Sikap diskriminatif yang ditunjukkan oleh pendapat-pendapat ahli hukum Islam klasik awal ini sangat menonjol.

${ }^{66}$ Ibn Qudâmah, al-Sharh al-Kabîr, op.cit., Jilid V, pp. 619-623.

${ }^{67}$ Ibn Qayyim al-Jauziyyah (1995/1415), Abkâm Ahl al-Dzimmah, (ed.) Thaha Abd Rauf Sa'ad, II Jilid, Beirut :Dâr al-Kutub al-Ilmiyyat, Jilid II, pp. 143, 154.

68 al-Mimmi, op.cit., p. 129.

${ }^{69}$ Ibn Qayyim, op.cit., p. 125.

${ }^{70}$ D.B. Macdonald (1913), "Dhimma," dalam Encyclopédie de l'Islam, diedit oleh M. Th. Houtsma, R. Basset, TW. Arnold dan R. Hartmann, Leiden dan Paris: EJ. Brill dan Picard, p. 984.

${ }^{71}$ Ignaz Goldziher, 1913, “Ahlul Kitab," dalam Encyclopédie de l'Tslam, diedit oleh M. Th. Houtsma, R. Basset, TW. Arnold dan R. Hartmann. Leiden dan Paris: EJ. Brill dan Picard, pp. 188-9.

${ }^{72}$ H.A.R. Gibb dan JH. Kramers (1991), Shorter of Engyclopaedia of Islam, Leiden:EJ.Brill, pp. 1617.

${ }^{73}$ Bleuchot, op.cit., pp. 76-79. 


\section{Penilaian atas Pandangan Fukaha .}

Jika dilihat dari kaca mata kekinian, pandangan para fakih terhadap nonmuslim jelas sangat diskriminatif dan sangat buruk. Pandangan mereka bisa menjadi akar konflik hubungan antara Islam dan non-Islam. Tegasnya, doktrin hukum Islam yang ekslusif dapat menjadi peletup konflik antaragama di dunia ini. Adanya gejolak permintaan penerapan hukum Islam yang menguat di berbagai belahan dunia belakangan ini cukup mengkhawatirkan kalangan non-muslim.

Tentu, menerapkan hukum Islam yang terjabarkan dalam kitab-kitab karangan para fakih klasik awal ini saat sekarang sangat tidak televan dan bertentangan dengan nilai-nilai demokrasi, seperti hak asasi manusia, persamaan, dan kebebasan berpendapat dan beragama. Karenanya, tidak mungkin menerapkan hukum Islam yang dibuat oleh para fakih klasik yang hanya cocok pada masanya. Oleh karena itu, adalah penting memahami mengapa para fakih klasik awal Islam ini mengeluarkan pendapat yang sangat 'ketas' untuk non-muslim. Kita akan mencoba melihatnya dari konteks sejarah politik dan teologi, sehingga kita dapat 'mengerti' mengapa para ahli hukum Islam awal ini mengeluarkan pendapatnya sedemikian tupa terhadap non-muslim.

Keempat fukaha yang dijadikan rujukan dalam tulisan ini hidup pada abad IIIII H./VIII-IX M., yaitu pada akhir masa kekuasaan dinasti Umayyah dan paruh pertama kekuasaan dinasti Abbasiyyah. Pada paruh kedua kekuasaan dinasti Umayyah mengalami krisis politik yang luar biasa, hal itu terjadi sekitar tahun 717$750 \mathrm{M}$. Tahun-tahun, setelah kematian Harun al-Rasyid, ini terjadi pemberontakan di mana-mana. Agama dijadikan alat propaganda untuk melawan penguasa Umayyah mulai dari Khurasan (Iran), Kufah (Irak), hingga Afrika Utara. Di saat krisis politik Umayyah, muncullah pemberontakan awal Abbasiyyah yang dimulai di Iran tahun 747 M. Pada akhirnya, penguasa terakhir Umayyah, Matwan, kalah dalam perang tahun 750 M., dan dieksekusi mati di Kairo setelah melarikan diri. Setelah itu lahirlah dinasti baru, yaitu Abbasiyyah. Paruh pertama kekuasaan Abbasiyyah juga mengalami hal yang sama; Pemberontakan terjadi di mana-mana ${ }^{74}$. Pada saat yang bersamaan daetah taklukkan yang dilakukan oleh Umayyah, kemudian dilanjutkan oleh Abbasiyyah semakin luas. Benua Afrika, Asia dan Eropa dikuasai oleh umat Islam.

Dengan melihat konteks sejarah politik masa di mana keempat fukaha itu hidup, maka nampak bahwa mereka hidup -pada saat krisis politik internal umat Islam dan sekaligus ekspansi besat-besaran oleh penguasa Islam ke betbagai penjuru dunia. Untuk memperkokoh ${ }^{-}$persatuan umat Islam dan menjaga supremasi Islam atas agama lain di daerah yang ditaklukkan, maka, mungkin sekali, para keempat ahli hukum Islam tersebut mengeluarkan ijtihad hukum mereka yang menurut kita

${ }^{74}$ Bleuchot, op.cit., pp. 81-82. 
sekarang sangat diskriminatif dan keras, tetapi sangat tepat dan cocok untuk konteks masa itu. Umat Islam butuh konsolidasi internal dan supremasi, maka hanya hukum yang bisa 'berbuat banyak' bagi umat Islam saat itu.

Mengapa hukum menjadi lebih dominan saat itu? Dalam konteks sejarah teologi Islam, masa-masa itu juga tengah terjadi perang teologi di dalam tubuh umat Islam. Abad II H./VIII M. merupakan masa gejolak intelektual yang penuh dengan tendensi sekte dan aliran teologi. Saat itu ada dua aliran besar dalam Islam: Qadariyyah dan Jabbariyyah. Qadariyyah berpaham bahwa manusia mampu dan bisa menciptakan perbuatannya sendiri. Manusia itu bebas, dengan kapasitas intelektualnya dapat menentukan baik-buruk dan bertanggung jawab atas semua perbuatannya. Pada gilirannya Qadariyyah akan melahirkan paham Muktazilah. Bagi pemikir aliran ini ; Ilmu kalam harus menjadi jantung Islam.

Jabbariyyah berpaham kebalikan dari Qadariyyah, yaitu bahwa manusia itu tidak bebas berbuat, karena semua perbuatannya sudah ditentukan oleh Allah. Jabbariyyah sendiri kemudian melahirkan paham Asy'ariyyah. Para pemikir yang mengikuti alitan kedua ini adalah kaum tradisionalis atau Ahlus Sunnah. Para ahli hukum Islam awal hampir semuanya mengikuti paham ini ${ }^{75}$ (kecuali Hanafi). Oleh karena itu, bagi mereka hukum harus menjadi jantung Islam. Hukum adalah segalagalanya. Pertarungan kedua aliran teologi, pada akhirnya, dimenangkan oleh aliran kedua yang pro-hukum.

Pada tahap selanjutnya, hukum memainkan peranan yang penting di dalam tubuh umat Islam. Karena posisi strategis ini, maka, dengan segala kemungkinan, para ahli hukum Islam awal ini membuat ijtihad hukum mereka, seperti yang telah dipaparkan di atas, untuk menjaga supremasi umat Islam atas umat-umat lain. Nuansa politis dari ijtihad hukum keempat fakih ini sangat kentara. Tujuannya tak lain adalah kekuasaan dan kontrol penuh atas non-muslim dalam segala hal.

\section{E. Penutup}

Status hukum non-muslim dalam kitab-kitab fikih, seperti yang telah dipaparkan di atas, berada dalam posisi serba terbatas. Non-muslim mengalami perlakuan yang tak sama di depan hukum; sumpah non-muslim tidak diterima, nonmuslim tidak pernah bisa bersaksi melawan muslim, diyat non-muslim dihargai hanya setengah dari diyat muslim dan lainnya. Dalam menjalankan ajaran agama, nonmuslim mengalami bermacam-macam diskriminasi seperti pelarangan mendirikan gereja di Dâr al-Islâm. Untuk úrusan publik tetap menjadi hak ekslusif umat Islam,

${ }^{75}$ Sami Awad Al-Deeb Abu-Sahlieh (1979), Non-musulmans en Pays d'Islam, Zurich: Universitaires Fribourg Suisse, pp:49-59. Lihat juga Abdullahi Ahmed An-Naim (1997), Dekontruksi Syariah, (Toward an Islamic Reformation, Civil Liberties, Human Rights and International Law), penerjemah Jadul Maula \& Imam Aziz, Yogyakarta:LKiS, pp. 172, 246, 337. 
non-muslim tidak mempunyai hak. Mereka tidak bisa menjadi kepala pemerintahan, menteri, hakim pengadilan, sekretaris, bendahata, sebab semua posisi itu hanya disediakan untuk Muslim ${ }^{76}$. Dalam masalah hukum keluarga dan perdata, non-muslim harus tunduk pada hukum Islam. Jika mereka terlibat suatu masalah dengan Muslim, maka hukum Islam yang harus diterapkan. Yang lebih mengherankan, para fakih klasik sudah a priori terlebih dahulu tethadap non-muslim sebelum membuktikannya terlebih dahulu, seperti pendapat yang mengatakan bahwa non-muslim itu tidak adil. Bagaimana para fakih tahu bahwa semua non-muslim itu tidak adil? Apakah juga semua muslim itu adil ? Menurut penulis, hal seperti itu adalah penilaian yang tergesa-gesa dan mengada-ada.

Persoalan yang terbesar mengapa non-muslim harus menjadi sasaran hukum Islam, yang dijabarkan dari keyakinan keagamaan umat Islam. Nampaknya, keadaan seperti ini merupakan akibat langsung dari status dzimmi yang disandang oleh para non-muslim yang tinggal di daerah pemerintahan Islam. Mereka ditekan dan dikuasai melalui status dzimmi. Maka dzimmah menjadi contoh hukuman formal yang disahkan. Dengan kata lain, politik dzimmah dalam hukum Islam yang dibetlakukan kepada non-muslim adalah keberhasilan politik arabisasi dan Islamisasi penduduk asli ${ }^{77}$.

\section{DAFTAR PUSTAKA}

Abu-Sahlieh, Sami Awad al-Deeb (1979), Non-musulmans en pays d'Islam, Zurich: Universitaires Fribourg Suisse.

al-'Ik, Khâlid Abd Rahmân (1993/1413), Mawsûatu al-Fiqb al-Maliki, VI jilid, Damaskus: Dâr al-Hikmat.

al-Jazînî, Abd Rahmân (1987/1406), Kitâb al-Fiqh 'ala Madzâbibi al-Arba'ah, V jilid, Beirut: Dâr al-Fikt.

al-Jurjânî, Ali ibn Muhammad (1978), Kitab al-Ta'rifat, Beirut: Maktabat Lubnan. Ali, Maulana Muhammad (1990), Quran Sacre, penterjemah Gilles Valois, Ahmadiyyah Islam Lahore, USA.

al-Mimmî, Hasan (1998), Abl dzimmab Fî̀ al-Hadlârat al-Islâmiyyat, Beirut: Dâr alGharb al-Islâmi.

al-Sarakhsî, Shamsuddîn (1994/1414), al-Mabsît, XXX jilid, Beirut: Dâr al-Kutub al-Ilmiyyah.

al-Tanûkhî, Sahnûn Ibn Sa'ad (tanpa tahun), al-Mudannvanat al-Kubrâ Li al-Imâm Mâlik, Ali Ibn Abd Rahmân al-Hâshimî (ed.) XI jilid, Kairo: Dâr al-Nashr. 
An-Naim, Abdullahi Ahmed (1997), Dekontruksi Syariab, (Toward an Islamic Reformation, Civil Liberties, Human Rights and International Law), penerjemah Jadul Maula \& Imam Aziz, Yogyakarta: LKiS.

Becker, C.H. (1913), "Djizya," dalam Encyclopédie de l'Islam, diedit oleh M. Th. Houtsma, R. Basset, TW. Arnold dan R. Hartmann, Leiden dan Paris: EJ. Brill dan Picard.

Bleuchot, Hervé (2002), Droit Musulman, jilid II: Histoire, Aix-en-Provence: Presses Universitaires d'Aix Marseille.

Gibb, H.A.R., dan JH. Kramers, ed. (1991), Shorter of Encyclopaedia of Islam, Leiden: EJ. Brill.

Goldziher, Ignaz (1913), “Ahlul Kitab," dalam Encyclopédie de l'Islam, diedit oleh M.Th. Houtsma, R. Basset, TW. Arnold dan R. Hartmann, Leiden dan Paris: EJ. Brill dan Picard.

(1991), Pengantar Teologi dan Hukum Islam (Introduction to Islamic Theology and Law), penerjemah Hersri Setiawan, Jakarta: INIS.

Ibn Mandzhûr, (tanpa tahun), Lisân al-'Arab, VI vols, Vol. III, Beirut: Dâr al-Ma'arif. Ibn Qayyim, al-Jauziyyah (1995/1415), Abkâm Abl al-Dzimmah, Thaha Abd Rauf Sa'ad (ed.), II jilid, Beirut: Dât al-Kutub al-Ilmiyyat.

Ibn Qudâmah, Muwaffaq al-Dîn (1983/1403), al-Mughnî, XIII jilid, Beirut: Dât alKutub al-'Araby.

Ibn Qudâmah, Shamsuddîn (tanpa tahun), al-Sharh al-Kabîr, VII jilid, Beirut: Dâr alFikr.

Johansen, Baber (1999), "The Muslim Fikh as a Sacred Law. Religion, Law and Ethics in a Normative System." dalam Contingency in Sacred Law: Legal and Ethical Norms in the Muslim Fikh, Leiden: Brill.

Macdonald, D.B. (1913), “Dhimma,” dalam Encyclopédie de lTslam, ed. M. Th. Houtsma, R. Basset, TW. Arnold dan R. Hartmann, Leiden dan Paris: EJ. Brill dan Picard. Millot, Louis et François-Paul Blanc (1987), Introduction à l'Etude du Droit Musulman,

Paris: Sirey.

Sâbiq, Sayyid (1988/1409), Figh Sunnah, III jilid, Kairo: tanpa nama penerbit. Schacht, Joseph (1999), Introduction au Droit Musulman, pent. Paul Kempf dan Abdel Magid Turki, Paris: Maisonneuve \& Larose.

Shâfi'i, Muhamad Ibn Idtîs (tanpa tahun), al-Umm, Muhammad Zuhri al-Najjâr (éd.), VII jilid, Beirut: Dâr al-Ma'rifat.

Ye'Or, Bat (1980), Le Dhimmi: Profil de l'Opprimé en Orient et en Afrique du Nord Depuis la Conquête Arabe, Paris: Anthropos. 